\title{
Effect of seed priming on bitter gourd with different sources of phosphorus at various soaking durations
}

\author{
Kamran Khurshid Baig, Neelam Ara, Shujaat Ali", Bilal Pevaiz Khan, \\ Abdul Wahab and Umer Rabbani \\ The University of Agriculture Peshawar Khyber Pakhtunkhwa-Pakistan \\ *Corresponding author's email: shujat.swati@gmail.com \\ Citation \\ Kamran Khurshid Baig, Neelam Ara, Shujaat Ali, Bilal Pevaiz Khan, Abdul Wahab and Umer Rabbani. Effect of \\ seed priming on bitter gourd with different sources of phosphorus at various soaking durations. Pure and Applied \\ Biology. Vol. 9, Issue 1, pp80-90. http://dx.doi.org/10.19045/bspab.2020.90010
}

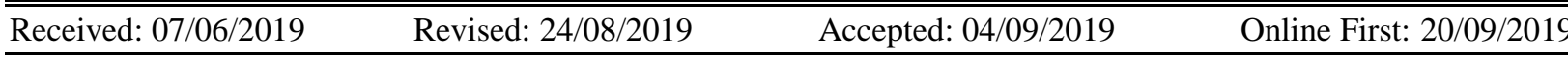

\section{Abstract}

The field experiment was conducted out on the effect of seed priming on bitter gourd cv, Jaunpuri with different sources; distilled water and $1 \%$ of $\mathrm{P}$ using Di-ammonium phosphate, single supper phosphate and combination of $\mathrm{SSP}+\mathrm{Na}_{2} \mathrm{CO}_{3}$ at different soaking durations $(6,12,18,24$ hours) with control treatment at new developmental farm (Horticulture section), The University of Agriculture Peshawar, Khyber Pakhtunkhwa during summer, 2016. The 20 treatments were three times replicated in Randomized Complete Block design with two factorial experiment i.e. sources and soaking durations. The result showed that seed priming significantly affected the emergence, vegetative and reproductive attributes of bitter gourd. The mean results showed that, higher percent of germination (78.14\%), survival percentage $(83.57 \%)$, days to early emergence (7.42), days to early flowering (38.67), primary branches palnt $^{-1}(8.39)$, number of fruits plant ${ }^{-1}(13.97)$, fruit weight (101.36 g), fruit yield ha ${ }^{-1}$ (23.37 tones) and seed yield ha- ${ }^{-1}(1091.62 \mathrm{~kg})$ were observed While less days to emergence (7.42) was recorded when seeds were soaked in SSP $+\mathrm{Na}_{2} \mathrm{CO}_{3}$ solution. Maximum fruit length $(14.84 \mathrm{~cm})$ and number of seed fruit ${ }^{-}$ ${ }^{1}(22.83)$ were recorded when seeds were primed in DAP solution. SSP $+\mathrm{Na}_{2} \mathrm{CO}_{3}$ performed best in germination percentage. DAP also showed best performance in most of the parameters. While, no major changes were observed for emergence and yield contributing characters in distilled water treatment. Unprimed seed showed poor performance as compared to primed seeds. Hence, Seed priming in neutralized SSP for 24-hour soaking duration is recommended for improving germination and fruit yield.

Keywords: Bitter gourd, Distilled water, Quantitative attributes Seed priming, Soaking durations

\section{Introduction}

Bitter gourd (Momordica charantia L.) is tropical and sub-tropical vine and considered as major crop of Cucurbitaceae family, widely grown in Asia and Africa for its edible fruit. It has the more bitter taste as compared to other cucurbits. It is originated from Asia and America [1] and is considered a valued vegetable because of its medicinal and high nutritive values due to presence of ascorbic acid and iron [2]. It is habitually cultivated annual plant but it can also grow as a perennial in slightly warm areas having frost free winter. The summer annual season crop sown from January to June in plain areas [3].

The plants can grow in alkaline soil having $\mathrm{pH}$ upto 8 but thrives best in the optimum soil $\mathrm{pH}$ range 6 to 6.7 [4]. Bitter gourd is cultivated on 5971 hectares with an average 
production of 56,949 tons in Pakistan, whereas the total of 749 hectares was under the cultivation of bitter gourd in Khyber Pukhtunkhwa, with a net production of 68595 tons during 2014-15 [5].

Bitter gourd is considered most important vegetable crop because of its high medicinal values. A charatin compound exists in the bitter gourd that is used in the curing of diabetes to regulate blood sugar levels normally. The roots, stem, leaves and fruits of bitter gourd have been used in conventional medicine to assist curing disorder such as hyperlipidemia, digestive disarray, menstrual problems, and microbial infections [6]. Due to anti carcinogenic properties of bitter gourd it can be used as cyto toxic agent against many kinds of cancer [7].

In bitter gourd, seedlings are transplanted directly to field but direct seeding is the most common production practice. The seed of bitter gourd bears hard seed coat which cause delayed emergence due to slow absorption of water. The speed of germination can be enhanced by pre-sowing treatments, like soaking of seeds in slightly warm water for 30 minutes and placed in a wet gunny bag or cloth bag for 3 to 4 days in a warm place. Poor seed germination is common at suboptimal temperatures [8].

Poor seedling germination, delayed emergence, less survival of plants and slow growth rate are the major problems of bitter gourd limiting the yield because the hard seed coat is surrounded around the embryo, which resist the embryo growth. The ideal temperature for germination of bitter gourd seeds is $25-28^{\circ} \mathrm{C}$ [8].

Phosphorus is one of the main fundamental nutrient which is needed by plants for their growth [9]. Phosphorus is an operational component of macro molecules required by plants during the rapid period of growth, such as nucleic acid, ADP, ATP, DNA and RNA. Phosphorus is also responsible to transfer and storage of energy in plants [10]. It is also allied with root growth and development and creates resistance and tolerance against root-rot diseases, improved fruit quality, triggered growth and prompted early maturity [11]. The phosphorus lies in range $0.05 \%$ to $0.5 \%$ in plants [12].

Nutrient priming in Phosphorus supports early stage of crop progress, improved the final yield and synchronizes the process of germination, especially in $\mathrm{P}$ lacking soil [13].

Seed priming in phosphorus amended solution is consider to be an efficient way to inject nutrients inside the seed embryo to improved early seedlings growth and providing phosphorus in early period of development particularly in phosphorus deficient soil [14].

Seed priming is most effective method in subtropical areas where low temperature effects seedling emergence and uniformity. It softens the seed coat, overcome the seed dormancy, resist the growth inhibitors and activate enzymes. It improves the Seed germination rate, uniformity of seedlings and reduced the time to emergence Priming permits seed to imbibe water and go through germination phase and after priming, seeds are dried back to its actual moisture level before radical protrusion [15].

The present study was under taken to observe the performance of bitter gourd after seed priming in various phosphorus sources at various soaking duration to find out the effective source and duration for improving germination percentage and quantity attributes.

\section{Materials and methods}

The experiment entitled "Effect of seed priming on bitter gourd with different sources of phosphorous at various soaking durations" was conducted at new developmental farm (Horticulture section), The University of Agriculture Peshawar, Khyber Pukhtunkhwa during summer, 2016. 
The features of field experiment were as under:

\section{Soil analysis}

Soil samples upto $20 \mathrm{~cm}$ were taken randomly from the different parts of field before sowing of seeds and examined in the Soil Science Laboratory at The University of Agriculture, Peshawar for bio chemical characteristics (Table 1).

Table 1. Chemical characteristics of research field

\begin{tabular}{|c|c|}
\hline Electrical conductivity & $0.74 \mathrm{ds} \mathrm{m}^{-1}$ \\
\hline $\mathrm{pH}$ & 8.1 \\
\hline Organic matter & $0.95 \%$ \\
\hline $\mathrm{P}_{2} \mathrm{O}_{5}$ & $0.096 \mathrm{mg} \mathrm{L}^{-1}$ \\
\hline Nitrogen & $1.0 \mathrm{mg} \mathrm{L}^{-1}$ \\
\hline
\end{tabular}

\section{Preparation of solutions}

Experiment comprised of two types of priming, hydro priming and nutrient priming. Calculated quantities of priming sources were dissolved in one liter of distilled water and prepared separately solutions of various concentrations.

\section{Hydro priming}

Seeds were soaked individually for different soaking durations in $250 \mathrm{ml}$ of distilled water in a beaker.

\section{Nutrient priming}

Nutrient priming treatment were prepared from DAP, SSP and SSP $+\mathrm{Na}_{2} \mathrm{CO}_{3}$ at $1 \%$ phosphorus concentration. Calculated amount of sources i.e. $149.5 \mathrm{~g}$ of DAP, $114.5 \mathrm{~g}$ of SSP or $12.5 \mathrm{~g}$ of $\mathrm{Na}_{2} \mathrm{CO}_{3}$ with the Factor A: Sources

$\mathrm{S}_{1}=$ Distilled water (D.W)

$\mathrm{S}_{2}=1 \% \mathrm{P}$ in Di - ammonium phosphate solution (DAP)

$\mathrm{S}_{3}=1 \% \mathrm{P}$ in Singer super phosphate solution (SSP)

$\mathrm{S}_{4}=1 \% \mathrm{P}$ in $\mathrm{SSP}+\mathrm{Na}_{2} \mathrm{CO}_{3}$
SSP were dissolved in water to make $1 \% \mathrm{P}$ solution volume upto 1 liter. The seeds were soaked in solutions in beaker for different durations in descending order. The seeds were taken from these solutions at one time, dried in air for 30 minutes at room temperature and were sown in the field.

\section{Experimental design}

Randomized complete block design (RCBD) was used to layout the experimental units.

There were two factors; Sources and soaking durations. Selected sources were kept in main plot while, different soaking durations were kept in subplot.

Treatments of both the factors are as follows:

\section{Factor B: Soaking duration (Hours)}

$\mathrm{D}_{1}=$ Un-soaked (control)

$\mathrm{D}_{2}=6 \mathrm{~h}$

$\mathrm{D}_{3}=12 \mathrm{~h}$

$\mathrm{D}_{4}=18 \mathrm{~h}$

$\mathrm{D}_{5}=24 \mathrm{~h}$ 


\section{Preparation of the field}

Before sowing the seed, the land was properly ploughed with tractor and planked them till got fine tilth. Before to sowing, weeds, pebbles, stones and residues of previous crop were removed. Field was leveled to ensured uniform and efficient distribution of water. Thereafter, divided the field into experimental units according to experimental layout. Field was comprised of 3 main plots and each main plot divided into 20 subplots. The size of subplot was $3 \mathrm{~m}^{2}$ $(1.5 \mathrm{~m} \times 2 \mathrm{~m})$. The distance $2 \mathrm{~m}$ was kept between main plot and $60 \mathrm{~cm}$ between subplots.

\section{Sowing of seeds}

The primed seeds along with un-primed were sown in the field at $2.5 \mathrm{~cm}$ depth by keeping $30 \mathrm{~cm}$ plant to plant distance. There were $150 \mathrm{~cm}$ long ridges for each treatment in which 18 seeds were sown only on single side of ridge. Seeds were covered with fine soil and pressed roughly. After seedling emergence, thinning was done to keep one plant. All cultural practices, such as weeding, hoeing, irrigation and other practices were practiced uniformly in field.

\section{Parameters studied}

\section{Germination percentage $(\%)$}

Germination percentage was calculated by counting number of germinated seeds out of the whole seed sown in the subplot.

The germination percentage was calculated by the following formula.

Germination \%age $=$ Entire No. of germination seeds $\times 100$ Entire seeds sown

\section{Days to emergence}

The data was recorded on the basis of number of days taken to seedlings emergence in each treatment of each replication right from the date of sowing and average of values were calculated.

\section{Survival percentage (\%)}

The data was determined by counting the entire number of plants survived out of the number of plant germinated.
The survival percentage was calculated by the given formulae: entire

Survival \%age $=$ Entire plants survived $\quad x 100$ Entire plants germinated

Number of primary branches plant ${ }^{-1}$

Number of branches plant ${ }^{-1}$ of randomly selected plants in each treatment of each replication were counted after final harvesting and their averages were calculated and expressed in number.

\section{Number of days to first flowering}

The observation was noted by counting the number of days taken from date of sowing up to appearance of first flowering in 50\% of the sampled plants in each treatment of each replication.

\section{Number of fruits plant ${ }^{-1}$}

The plants were selected on random basis in each subplot and were tagged. The total number of fruits obtained from selected plants were counted and cumulative after last harvesting and then average number of fruit per plants was calculated.

Fruit length $(\mathrm{cm})$

The fruit length was taken by measuring the fruit picked at green mature stage with scale from selected plants and their averages were calculated.

\section{Fruit weight (g)}

Ten selected fruit were weighted in electric balance at green mature stage and their average weight was calculated and expressed in grams.

Number of seeds fruit ${ }^{-1}$

For this purpose $8-10$ fruits plant $^{-1}$ were taken from the selected plants. The seeds were extracted out with the help of fruit cutter, counted and their average was calculated.

Fruit yield (tones ha-1)

Fruit yield was evaluated by using the following formula:

Yield ha- ${ }^{-1}=\underline{\text { Yield per sub plot }(\mathrm{Kg})} \times \mathbf{A 0 0 0 \mathrm { m } ^ { 2 }}$ Area of sub plot $\left(\mathrm{m}^{2}\right) \times 1000$

Seed yield $\left(\mathrm{kg} \mathrm{ha}^{-1}\right)$

Selected ripe fruits were harvested from randomly selected plants in each treatment 
of each replication and seeds were extracted from them. After extraction, seeds were separated from pulp and washed thoroughly with tap water, dried in air for 30 minutes and were weighed in kilograms. The values were expressed as seed yield $\mathrm{kg} \mathrm{ha}^{-1}$.

\section{Statistical analysis}

The data recorded were subjected to analysis of variance technique using statistical software STATISTICS 8.1 [16].

\section{Results}

Morphological behavior

The mean data regarding morphological characteristics of seed priming sources and soaking duration on bitter gourd were given (Table 2). The priming in different phosphate solution and various soaking duration had a significant effect morphological characteristics. The maximum germination percentage $(78.14 \%)$ was recorded when seeds were primed with $\mathrm{SSP}+\mathrm{Na}_{2} \mathrm{CO}_{3}$, chased by percent of germination $(74.44 \%)$ in primed seeds with DAP solution. While, minimum germination percentage $(66.66 \%)$ was observed when seed soaked in distilled water. In case of various soaking durations, the highest percent of germination $(86.97 \%)$ was gained when seeds were primed at 24 hours soaking duration, trailed by percent of germination $(80.90 \%)$ was observed, when seeds primed for 18 hours. While, least percent of germination $(53.70 \%)$ was obtained in unprimed seeds plot.

Similarly, the mean values of different sources revealed that the maximum days to emergence (8.55) were counted in treatments in which seeds were primed with distilled water., while minimum days to emergence (7.42) were noted when seeds were primed with $\mathrm{SSP}+\mathrm{Na}_{2} \mathrm{CO}_{3}$ solution. Likewise, soaking durations indicated that, more number of days (9.61) to emergence were observed when seeds were kept as unsoaked, trailed by Days were taken to emergence (8.18) in a treatment in which seeds were primed for 6 hours, while minimum days to early emergence (7.0) were recorded, when seed were primed for 24 hours.

Significant differences were recorded through survival of plants. The highest survival of plants $(83.57 \%)$ was observed when; seeds were primed in $\mathrm{SSP}+\mathrm{Na}_{2} \mathrm{CO}_{3}$ solution. Which statistically at par with DAP primed seeds having survival percentage $(78.59 \%)$, while seeds that were primed with distilled water recorded minimum survival percentage $(69.58 \%)$. In case of various soaking durations showed more percent of survival plants $(87.62 \%)$ after seeds were primed for 24 , which statistically at par with survival percentage $(82.00 \%)$ after 18 hours soaking duration. while minimum survival percentage $(62.11 \%)$ was noted in unprimed seeds.

In case of different sources, more numbers of primary branches (8.39) were produced when, seeds were primed with SSP $+\mathrm{Na}_{2} \mathrm{CO}_{3}$ solution, chased by primary branches (7.89) were produced in plants when seeds were primed with DAP solution. While, minimum numbers of branches (7.18) were produced in plants seeds which were soaked in distilled water. Similarly, the mean values soaking duration, the maximum (9.88) branches were counted in plants of seeds after primed for 24 hours. The next best soaking duration was found i.e. 18 hours having primary branches (8.55). While minimum primary branches (6.01) were counted in plants of un-primed seeds.

According to mean values of different sources, seeds soaked in distilled water showed maximum days to first flower (41.93) in plants which was traced by the days to first flower (40.71) in plants of which seeds were primed in SSP solution. While, seeds were primed in $\mathrm{SSP}+\mathrm{Na}_{2} \mathrm{CO}_{3}$ took minimum 38.67 numbers of days to first flower. Whereas, soaking durations 
showed, maximum days to first flowering (43.83) in plants of un-primed seeds, chased by the days to first flower (40.61) in plants of after seeds were primed for 6 hours. On the other hand, minimum days to flower (37.69) were noted in plants of when seeds were primed for 24 hours.

Table 2. Morphological behavior in bitter gourd as affected by seed priming in different phosphorus sources at various soaking durations

\begin{tabular}{|c|c|c|c|c|c|}
\hline $\begin{array}{l}\text { Phosphorus } \\
\text { sources }\end{array}$ & $\begin{array}{c}\text { Germination } \\
\text { percentage }\end{array}$ & $\begin{array}{c}\text { Days to } \\
\text { emergence }\end{array}$ & $\begin{array}{c}\text { Survival } \\
\text { percentages } \\
(\%)\end{array}$ & $\begin{array}{c}\text { Number of } \\
\text { primary } \\
\text { branches } \\
\text { plant }^{-1}\end{array}$ & $\begin{array}{l}\text { Number of } \\
\text { days to first } \\
\text { flower }\end{array}$ \\
\hline Dist.Water & $66.66 \mathrm{~d}$ & $8.55 \mathrm{~d}$ & $69.58 \mathrm{~d}$ & $7.18 \mathrm{c}$ & $41.93 \mathrm{a}$ \\
\hline DAP & $74.44 \mathrm{~b}$ & $7.90 \mathrm{~b}$ & $78.59 \mathrm{~b}$ & $7.89 \mathrm{~b}$ & $39.58 \mathrm{c}$ \\
\hline SSP & $70.65 \mathrm{c}$ & $8.15 \mathrm{c}$ & $73.90 \mathrm{c}$ & $7.66 \mathrm{~b}$ & $40.71 \mathrm{~b}$ \\
\hline $\mathrm{SSP}+\mathrm{Na}_{2} \mathrm{CO}_{3}$ & $78.14 \mathrm{a}$ & $7.42 \mathrm{a}$ & $83.57 \mathrm{a}$ & $8.39 \mathrm{a}$ & $38.67 \mathrm{~d}$ \\
\hline LSD at $\mathrm{P} \leq 0.05 \%$ & 3.547 & 0.2465 & 4.2337 & 0.4670 & 0.8945 \\
\hline \multicolumn{6}{|l|}{$\begin{array}{c}\text { Soaking } \\
\text { Durations (hours) }\end{array}$} \\
\hline 0 & $53.70 \mathrm{e}$ & $9.61 \mathrm{a}$ & $62.51 \mathrm{~d}$ & $6.01 \mathrm{e}$ & $43.83 \mathrm{a}$ \\
\hline 6 & $65.73 \mathrm{~d}$ & $8.18 \mathrm{~b}$ & $73.03 \mathrm{c}$ & $6.61 \mathrm{~d}$ & $40.61 \mathrm{~b}$ \\
\hline 12 & $74.99 \mathrm{c}$ & $7.78 \mathrm{c}$ & $76.89 \mathrm{c}$ & $7.84 \mathrm{c}$ & $40.05 \mathrm{~b}$ \\
\hline 18 & $80.96 \mathrm{~b}$ & $7.47 \mathrm{~d}$ & $82.00 \mathrm{~b}$ & $8.55 \mathrm{~b}$ & $38.92 \mathrm{c}$ \\
\hline 24 & $86.97 \mathrm{a}$ & $7.00 \mathrm{e}$ & $87.62 \mathrm{a}$ & $9.88 \mathrm{a}$ & $37.69 \mathrm{~d}$ \\
\hline LSD at $\mathrm{P} \leq 0.05 \%$ & 3.965 & 0.2756 & 4.7335 & 0.5221 & 1.0011 \\
\hline
\end{tabular}

\section{Yield and yield components}

The yield and yield components (Table 3) of fruits and seeds significantly affect with primed of different phosphorus sources and after soaking durations. Quantity of fruits in plants is the primary constituent of fruit and seed yield and it determines the ultimate production. It directly contributes towards the yield and represents reproductive efficiency of a crop. Seed production and productivity of the plants is largely influenced by number of fruits per plant. The mean values of experimental results regarding source indicated that seeds were primed with $\mathrm{SSP}+\mathrm{Na}_{2} \mathrm{CO}_{3}$ gives maximum fruits per plant (13.97) followed by number of fruits (13.27) were produced in plants when seeds were primed with DAP solution. While, minimum number of fruits (12.20) in plants were gained when seeds were soaked in distilled. Whereas, soaking durations showed maximum number of fruits (16.05) plants $^{-1}$ after seeds were soaked for 24 hours followed by number of fruits (15.00) for 18 hours, while minimum number of fruits (11.55) were recorded in un- primed seed plot.

In case of fruit length $(\mathrm{cm})$, the longest fruits $(14.84 \mathrm{~cm})$ was recorded in plants $^{-1}$ when seeds were primed with DAP solution, followed by fruit length $(14.03 \mathrm{~cm})$ was obtained when seeds were primed with $\mathrm{SSP}+\mathrm{Na}_{2} \mathrm{CO}_{3}$ solution, while minimum $(12.48 \mathrm{~cm})$ fruit length was recorded in plants when seeds were soaked in distilled water. According to mean values of different soaking durations, the maximum fruit length $(16.04 \mathrm{~cm})$ was obtained in plants of seeds which were primed for 24 hours, followed by fruit length $(14.63 \mathrm{~cm})$ in plants of seeds which were soaked at 18 hours soaking duration, while minimum fruit length $(11.56 \mathrm{~cm})$ was noted in unprimed seeds plants in term of fruit weight $(\mathrm{g})$ the 
maximum fruit weight (101.36 g) was gained in plants of seeds which were soaked in $\mathrm{SSP}+\mathrm{Na}_{2} \mathrm{CO}_{3}$ solution. This treatment is statistically at par with DAP primed seeds having fruit weight (97.90g).While, minimum fruit weight $(90.93 \mathrm{~g})$ was obtained when seeds were soaked in distilled water. In case of various soaking durations, maximum fruit weight $(107.70 \mathrm{~g})$ was obtained in plants of seeds which were soaked after 24 hours soaking durations. The next best soaking duration 18 hours was found having fruit weight $(100.37 \mathrm{~g})$. While, minimum $(85.30 \mathrm{~g})$ fruit weight was recorded in un-soaked seeds plants.

In case of maximum number of seeds fruits 1 , the maximum number of seeds were produced (22.83) per fruit when seeds were primed with DAP solution. This treatment is statistically at par with $\mathrm{SSP}+\mathrm{Na}_{2} \mathrm{CO}_{3}$ primed seeds having number of seeds fruit ${ }^{1}$ (21.63). While, lowest numbers of seeds (19.82) were counted, when seeds were soaked in distilled water. In the term of various soaking durations, maximum (23.33) seeds were counted, when seeds were primed for 24 hours. The next best soaking duration was observed i.e. 18 hours having 21.98 numbers of seed per fruit. The data in mean table is indicated that seed were primed for 6,12 and 18 hours had nonsignificant variations for number of seed fruit $^{-1}$ least 19.18 number of seeds were recorded in fruit of un-primed seeds.

The mean values for fruit yield $\mathrm{ha}^{-1}$ (tones) showed highest production per plant of seeds which were primed in $\mathrm{SSP}+\mathrm{Na}_{2} \mathrm{CO}_{3}$ solution. This treatment is statistically at par with DAP primed seeds having fruit yield $\mathrm{ha}^{-1}$ (21.38 tones), while seeds were primed with distilled water had recorded minimum (18.36 tones) yield $\mathrm{ha}^{-1}$. In the term of soaking durations, maximum (25.57 tones) fruit yield $\mathrm{ha}^{-1}$ was obtained in plants of seeds which were primed for 24 hours soaking durations. The next best soaking duration found was 18 hours having (22.42 tones) yield $\mathrm{ha}^{-1}$, while minimum (16.43 tones) yield ha ${ }^{-1}$ was recorded in un-primed seed plants.

Likewise, more seed yield ha ${ }^{-1}(1091.62 \mathrm{~kg})$ was obtained when seeds were primed with $\mathrm{SSP}+\mathrm{Na}_{2} \mathrm{CO}_{3}$ solution, than the seed yield $\mathrm{ha}^{1}(1027.83 \mathrm{~kg})$ was gained by plants of seeds which were primed in DAP solution. While, less seed yield ha-1 $(896.86 \mathrm{~kg})$ was recorded when seeds were soaked in distilled water. Whereas, more seed yield ha $1 \quad(1153.63 \mathrm{~kg})$ was obtained when seeds were primed for 24 hours during storage period than the seed yield ha ${ }^{1}(1054.60 \mathrm{~kg})$ was obtained, when seed primed for 18 hours. While lowest seed yield $(848.91 \mathrm{~kg})$ was noted in un-primed seed plants.

\section{Discussion}

The effects of different phosphorus sources and soaking durations on germination percentage is revealed that the priming in different phosphate solution and various soaking duration had a significant effect on percent of germination. The increment in percent of germination by soaking may be due the reason that it excites series of biochemical changes in the seed which are necessary to start the initial germination process, break the hard seed coat dormancy, activate enzymes, inhibit the activities of growth inhibitors and hydrolysis etc. [17] done. [18] Who, concluded that seed priming of spinach in SSP solution for 24 hours enhanced the early emergence and increased the germination percentage from $77.0 \%$ to $95.33 \%$. Seed priming in phosphate solution significantly reduced the emergence time over non-primed seed. Emergence is a necessary process for the good establishments of crop. For normal emergence, adequate amount of $\mathrm{H}_{2} \mathrm{O}$, nutrients, temperature, oxygen, soil types and viability of seeds play a vital role in the emergence. The findings of experimental results are in conformity of with the 
investigations of $[17,19]$.

Table 3. Yield and yield components in bitter gourd as affected by seed priming in different phosphorus sources at various soaking durations

\begin{tabular}{|c|c|c|c|c|c|c|}
\hline $\begin{array}{c}\text { Phosphorus } \\
\text { sources }\end{array}$ & $\begin{array}{c}\text { Number of } \\
\text { fruits } \\
\text { plant }^{-1}\end{array}$ & $\begin{array}{l}\text { Fruit } \\
\text { length } \\
(\mathrm{cm})\end{array}$ & $\begin{array}{c}\text { Fruit } \\
\text { weight }(\mathrm{g})\end{array}$ & $\begin{array}{l}\text { Number of } \\
\text { seeds fruit }^{-1}\end{array}$ & $\begin{array}{c}\text { Fruit } \\
\text { yield ha- } \\
1 \text { (tones) }\end{array}$ & Seed yield $\mathrm{kg} \mathrm{ha}^{-1}$ \\
\hline Dist.Water & $12.20 \mathrm{~d}$ & $12.48 \mathrm{~d}$ & $90.93 \mathrm{~d}$ & $19.82 \mathrm{c}$ & $18.36 \mathrm{~d}$ & $896.86 \mathrm{~d}$ \\
\hline DAP & $13.27 \mathrm{~b}$ & $14.84 \mathrm{a}$ & $97.90 \mathrm{~b}$ & $22.83 \mathrm{a}$ & $21.38 \mathrm{~b}$ & $1027.83 \mathrm{~b}$ \\
\hline SSP & $12.64 \mathrm{c}$ & $13.24 \mathrm{c}$ & $94.35 \mathrm{c}$ & $21.01 \mathrm{~b}$ & $19.56 \mathrm{c}$ & $964.15 \mathrm{c}$ \\
\hline $\mathrm{xSSP}+\mathrm{Na}_{2} \mathrm{CO}_{3}$ & $13.97 \mathrm{a}$ & $14.03 b$ & $101.36 \mathrm{a}$ & $21.63 \mathrm{~b}$ & $23.37 \mathrm{a}$ & $1091.62 \mathrm{a}$ \\
\hline $\begin{array}{c}\text { LSD at } \mathrm{P} \leq 0.05 \\
\%\end{array}$ & 0.4449 & 0.7580 & 3.4157 & 1.1707 & 1.0546 & 62.008 \\
\hline \multicolumn{7}{|l|}{$\begin{array}{c}\text { Soaking } \\
\text { Durations } \\
\text { (hours) }\end{array}$} \\
\hline 0 & $11.77 \mathrm{~d}$ & $11.56 \mathrm{~d}$ & $85.30 \mathrm{e}$ & $19.18 \mathrm{c}$ & $16.43 \mathrm{e}$ & $848.91 \mathrm{~d}$ \\
\hline 6 & $12.54 \mathrm{c}$ & $12.64 \mathrm{c}$ & $91.70 \mathrm{~d}$ & $20.67 \mathrm{~b}$ & $18.82 \mathrm{~d}$ & $940.63 \mathrm{c}$ \\
\hline 12 & $12.84 \mathrm{c}$ & $13.37 \mathrm{c}$ & $95.54 \mathrm{c}$ & $21.46 \mathrm{~b}$ & $20.08 \mathrm{c}$ & $977.79 \mathrm{c}$ \\
\hline 18 & $13.59 \mathrm{~b}$ & $14.63 \mathrm{~b}$ & $100.37 \mathrm{~b}$ & $21.98 \mathrm{~b}$ & $22.42 \mathrm{~b}$ & $1054.60 \mathrm{~b}$ \\
\hline 24 & $14.37 \mathrm{a}$ & $16.04 \mathrm{a}$ & $107.76 \mathrm{a}$ & $23.33 \mathrm{a}$ & $25.57 \mathrm{a}$ & $1153.63 \mathrm{a}$ \\
\hline $\begin{array}{c}\mathrm{LSD} \text { at } \mathrm{P} \leq 0.05 \\
\%\end{array}$ & 0.4974 & 0.8475 & 3.8188 & 1.3089 & 1.1790 & 69.327 \\
\hline
\end{tabular}

The present investigations are agreed with findings of [20] who recorded minimum 5.90 days to emergence, when seeds of bitter gourd were soaked in water for 16 hours and 8 days were recorded by unsoaked seed. [21] Reported that seed priming in phosphate solution activates the enzymes and antioxidative activities, inactivates the pathogenic activities, caused leaching of growth inhibitors to aqueous solution and enhanced the early emergence, produce vigorous seedlings and increase survival of plants. Similarly, [22] also reported that maximum survival of plants was observed when okra seeds were primed in SSP solution for 24 hours. The numbers of primary branches were counted more in primed seeds as compared to un-primed seeds. Early emergence and well establishment of crops caused more vegetative growth and increased plant height, branches and leaves which created cooperative competition for water, nutrients and light resulted in more vigorous plants [23]. [18] Who also described that, more vigorous seedlings and leaf area were obtained by seed priming in phosphate solution in maize and spinach, respectively. Shukla .2013. Reported that seed priming triggers early flowering which is considered to be a change from vegetative to reproductive phase of the crop growth.. Sooner the flower appears; earlier the yield and more are the profits. [22] Who revealed that primed seeds emerged fast, reduced time to flowering and give higher yield in cucumber and wheat. Number of fruits has directly interlinked with the number of branches and leaves. The present observations are in the agreement with findings of [24] who concluded that, seed primed in SSP solution for 24 hours improved yield parameters in okra and increased number of pods from 19.97 to 
45.26 when compared to un-primed seed. [23] Who reported the significant effect of seed priming, increased the number of fruits, fruit length, fruit weight and final yield of bitter gourd and cucumber. Fruit length is an important character, which determines crop yield and mostly lengthy fruit preferred by consumer. [23] who documented that, priming in one percent SSP solution for 24 hours not improved not only germination and vegetative characters but also improved the yield contributing characters, like fruit length and fruit weight . [25] Who recorded the maximum average fruit length $16.43 \mathrm{~cm}$ in bitter gourd when seeds were primed with cocopeat. Quality and productivity of bitter gourd depend on fruit weight. [26] Who reported that fruit weight was highly influenced by seed priming in phosphate solutions. Seeds priming in $\mathrm{SSP}+\mathrm{Na}_{2} \mathrm{CO}_{3}$ solution for 24 hours increased the fruit weight may be due to the reason that seeds absorbed adequate phosphorus, which enhanced the germination rate and produced healthy plants, and ultimately produced healthy fruits. [25] reported that fruit weight $(374.50 \mathrm{~g})$ was recorded maximum when seed were primed in PEG 6000 for 24 hours followed by $\mathrm{NaHPO}_{4}$ for 24 hours while, minimum $(343.20 \mathrm{~g})$ was gained in plants of un-soaked seeds. Phosphorus priming improved the bitter gourd performance and resulted in more number of seeds per fruit as compared to unprimed seed. [23, 18] Evaluated that; phosphorus seed priming not only improved the vegetative characters but also improved reproductive characters and increased the quantity of seed in okra and spinach. The prime purpose of growing crop is to have higher yield for better returns. [26] Who reported that adequate amount of phosphorus possibly has resulted in maximum ATP and DNA production and hence may have activated the metabolic and anti- oxidative activities. [23] Also reported similar results that higher $5063.53 \mathrm{~kg} \mathrm{ha}^{-1}$ pod yield was obtained when seed were soaked in $1 \%$ SSP solution for 24 hours, while minimum $1507 \mathrm{~kg} \mathrm{ha}^{1}$ pod yield was gained in un-primed seed plants of okra. [27] Recorded the maximum (154.49 $\mathrm{q} \mathrm{ha}^{-1}$ ) in primed seeds while minimum $\left(61.39 \mathrm{q} \mathrm{ha}^{-}\right.$ $\left.{ }^{1}\right)$ obtained in un- primed seed plants of bitter gourd. Quantities of fruits, number of seeds in fruits and seed weight are the major components of seed yield which concludes the final production and reproductive efficiency of crop. [25] Reported that maximum number of fruits were recorded were observed when seed were primed in $\mathrm{SSP}+\mathrm{Na}_{2} \mathrm{CO}_{3}$ for 24 hours. Similar findings were also reported by [28] who noticed more number of grains per pod and grain yield in primed seeds.

\section{Conclusion}

It is concluded that Seed priming in phosphorus solution has potential to overcome the problem of poor germination, delayed emergence, less survival of seedlings after emergence. seed priming in neutralized SSP solution for 24 hours, followed by DAP solution effectively enhanced emergence, seedling vigor, survival percentage $(\%)$, number of branches plant $^{-1}$,fruit weight, number of fruits per plant and finally fruit yield $\mathrm{ha}^{-1}$ of bitter gourd. Seed priming in DAP solution improved the seed fruit length $(\mathrm{cm})$, and increased no of seed fruit $^{-1}$. Among the various soaking duration, 24 hours soaking duration improved germination characteristics of bitter gourd seed and enhanced yield. Seed priming in distilled water improved minimum emergence and quantitative attributes as compared to phosphorus seed priming. Un-primed seed results in poor performance in germination, vegetative, and reproductive attributes of bitter gourd. 


\section{Authors' contributions}

Supervised my experiment: N Ara, Statistical analysis: BP Khan, A Wahhabi \& U Rabbani, Paper preparation: S Ali.

\section{Acknowledgments}

I am very grateful to Co-Authors for assistance with the Preparation of the manuscript on proper time.

\section{References}

1. Behera T (2011). Genetic diversity analysis and inheritance of fruit traits in bitter gourd (Lomordica charantia L.). IARI, 1 genetic diversity analysis and inheritance of fruit traits in bitter.

2. Rahman AH (2003). Bottle gourd (Lagenaria siceraria) a vegetable for good health. Natural Product Radiance 2: 249-50.

3. Singh N (2006). Vegetable seed production technology. International Book Distributing Co. Place.

4. Desai U \& Musmade A (1998). Pumpkins, squashes, and gourds. In Handbook of Vegetable Science and Technology. CRC Press, pp 291-354

5. MINFAL. 2015. Fruit, vegetables and condiments statistics of Pakistan. Govt. of Pakistan, Ministry of Food and Agriculture (Economic wing) Islamabad, pp 11-18.

6. Yibchok-Anun S, Adisakwattana S, Yao CY, Sangvanich P, Roengsumran S \& Hsu WH (2006). Slow acting protein extract from fruit pulp of Momordica charantia with insulin secretagogue and insulinomimetic activities. Biol and Pharmaceutical Bull 29: 1126-31.

7. Grover J \& Yadav S (2004). Pharmacological actions and potential uses of Momordica charantia: a review. J of Ethnopharmacol 93: 123-32.

8. Peter K, Sadhu M, Raj M \& Prasanna K (1998). Improvement and cultivation: Bitter gourd, snake gourd, pointed gourd, and ivy gourd.

9. Lott JN, Ockenden I, Raboy V \& Batten
GD (2000). Phytic acid and phosphorus in crop seeds and fruits: a global estimate. Seed Sci Res 10: 11-33.

10. Bieleski R \& Ferguson I. 1983. Physiology and metabolism of phosphate and its compounds. In Inorganic plant nutrition. Springer 422449.

11. Williamson LC, Ribrioux SP, Fitter AH \& Leyser HO (2001). Phosphate availability regulates root system architecture in Arabidopsis. Plant Physiol 126: 875-82.

12. Fohse D, Claassen N \& Jungk A (1988). Phosphorus efficiency of plants. Plant and Soil 110: 101-9.

13. Kaur H, Chawla N \& Pathak M (2015). Effect of different seed priming treatments and priming duration on biochemical parameters and agronomic characters of okra (Abelmoschus esculentus L.). Intl J of Plant Physiol and Biochem 7: 1-11.

14. Valdes V \& Bradford K (1987). Effects of seed coating and osmotic priming on the germination of lettuce seeds. J of the American Soc for Horticul Sci (USA).

15. Halmer P (2000). Commercial seed treatment technology. Seed Technology and Its Biological Basis. Sheffield Academic Press, Sheffield, England, pp 257-286.

16. Jan MT, Shah P, Hoolinton PA, Khan MJ \& Sohail Q (2009). Agriculture research: Design and analysis. Dept. Agronomy, KPK Agric Uni Peshawar, Pakistan.

17. Farooq M, Basra S, Wahid A, Khaliq A \& Kobayashi N (2009). Rice seed invigoration: a review. In Organic farming, pest control and remediation of soil pollutants. Springer 137-75.

18. Alam A, Amin N, Ara N, Ali M \& Ali I (2013). Effect of various sources and durations of priming on spinach seeds. Pakistan Journal of Botany 45: 773-7. 
19. Gallardo K, Job C, Groot SP, Puype M \& Demol H et al. (2001). Proteomic analysis of Arabidopsis seed germination and priming. Plant Physiol 126: 835-48.

20. Saleem MS, Sajid M, Ahmed Z, Ahmed S, Ahmed N \& Islam S (2014). Effect of seed soaking on seed germination and growth of bitter gourd cultivars. J Agric Vet Sci 6: 7-11.

21. Harris D, Joshi A, Khan P, Gothkar P \& Sodhi P (1999). On-farm seed priming in semi-arid agriculture: development and evaluation in maize, rice and chickpea in India using participatory methods. Experimental Agric 35: 15-29.

22. Harris D, Raghuwanshi B, Gangwar J, Singh S \& Joshi K et al. (2001). Participatory evaluation by farmers of on-farm seed priming in wheat in India, Nepal and Pakistan. Experimental Agric 37: 403-15.

23. Shah AR, Ara N \& Shafi G (2011). Seed priming with phosphorus increased germination and yield of okra. African J of Agric Res 6: 3859-76.

24. Rashid A, Harris D, Hollington P \&
Khattak R (2002). On-farm seed priming: a key technology for improving the livelihoods of resourcepoor farmers on saline lands. In Prospects for saline agriculture. Springer, pp 423-31.

25. Raturi HC (2013). Studies on seed priming in cucumber (Cucumis sativus L.) (Doctoral dissertation).

26. Ghassemi-Golezani, K \& Esmaeilpour B (2008). The effect of salt priming on the performance of differentially matured cucumber (Cucumis sativus) seeds. Notulae Botanicae Horti Agrobotanici Cluj-Napoca 36(2): 67-70.

27. Mehta D, Kanwar H, Thakur A, Thakur S \& Thakur K (2014). Standardization of seed hydro-priming duration in bitter gourd, Momordica charantia L. Intl J of Bio-resource and Stress Manag 5: 98101.

28. Rashid A, Harris D, Hollington $\mathrm{P} \&$ Rafiq M (2004). Improving the yield of mungbean (Vigna radiata) in the North West Frontier Province of Pakistan using on-farm seed priming. Experimental Agric 40: 233-44. 